\title{
Perspectives on Technology Transfer Strategies of Korean Companies in Point of Resource and Capability Based View
}

\author{
Seung-Ho Park ', Yong-Gil Lee ${ }^{2}$
}

\begin{abstract}
Technology transfer (or sharing) is a common way to share external sources. There have been many studies on the relationship of self-R\&D and technology transfer regarding its theoretical background and its efficiency. This present research has been developed by examining how a concrete measure of a company or a firm's real performance (increased sales ratio; growth rate) is related to the variables of resources and capabilities using the resource-based theory and open innovation model. The approach of this research is unique in that it examines a sample comprising of licensing-in and technological cooperation variables, categorizes forms according to industry, and looks at such unique variables as a "process" (the ratio of CEO's and related-person's stocks). The data on 36I Korean firms was gathered from Korea's Data Analysis, Retrieval, and Transfer System and Worldwide Intellectual Property Search. Findings show that human, technology, and fixed assets are related positively to financial performance, and searching, absorbing, and openness capabilities as a control effect is related positively to a firm's increased sales ratio. Strategic plans for technology transfer companies are also included in this research.
\end{abstract}

Keywords: R\&D outsourcing; technology transfer; resource-based theory; open innovation; performance.

\footnotetext{
' Korea Institute of Science \& TechnologyEvaluation and Planning, 68, Mabang-gil, Seocho-gu, Seoul, Korea I37-I30 (spark805I@gmail.com)

${ }^{2}$ Korea Research Institute for Vocational Education and Training, I5-I, Cheongdam-Dong, Kangnam-Gu, Seoul, Korea I35-949

(Corresponding author: leedomingo@krivet.re.kr,_Tel: +82-2-3485-5160)
} 


\section{Introduction}

In this rapidly changing global economy, technological innovation has become more important due to technology trajectory, short product life cycle, and globalization. For business firms, acquiring innovative technologies can be a source of a firm's long term success. Technology strategy has become one of the most significant factors for a firm to consider when making a business decision.

There are two ways to obtain technology to increase a firm's competitiveness: self-R\&D and technology transfer. For firms with sufficient technological capabilities and finances, self-R\&D strategy is a good option in creating their own innovations such as patents and processes. However, it is time consuming, expensive, and risky as it is impossible to take back the efforts in case of failure. Twiss (1974) defines technology import as the act of buying other companies' R\&D results for its profits and advantages. Reasons for acquiring technology from others include: the need for target technology, it is an easier way to enter a specific market compared to self-R\&D or imitation, the reduction of R\&D periods, and the use of patents with no risk. However, there are several disadvantages of technology import such as unknown cash flows for its future high costs, high consulting fees for training, and limitations of contract articles. Nevertheless, technology transfer is an alternative way to improve and adopt technologies from others; it can also build up the company's own technological abilities.

R\&D and technology transfer are viewed to have one of two contrasting types of relationships. The conventional view is that they have a substitute relationship. If a firm's budget for technology is already set, increasing technology import means decreasing self-R\&D. The more a firm is dependent on import technology, the less effort it makes to enhance its own technological ability. Basant and Fikkert (1996), Lee (1996), and Chuang and Lin (1999) have examined this substitute relationship empirically. Also, Evenson and Deolaikar (1989) claim that the government of India should decrease technology import from other advanced countries for the development of India's own technological abilities based on this substitute relationship.
The other type of relationship is a complementary relationship, which means that technology transfer will accelerate self-R\&D ability. Odagiri (1983) and Braga and Wilmore (199I) claim technology import can stimulate the increasing of a firm's own technology capabilities. From this viewpoint, imported technologies can be a catalyst for research and development activities. Even if the source of technology accumulation is derived from technology import, self-R\&D activity is essential in improving and reforming it. An efficient way to distribute technology transfer and self-R\&D activities is to upgrade the firm's value. Many empirical studies have examined how technology transfer influences investment of self-R\&D expenditure. Most of these studies show that a complementary relationship does exist between technology transfer and self-R\&D, confirming that there is a positive effect (Odagiri, 1983; Braga and Wilmore, 1991; Deolalikar and Evenson, 1993; Zaho, 1995; Hu et al., 2005).

This present study primarily focuses on the complementary relationship between technology transfer and selfR\&D. Previous research studies have been interested in the relationship between technology transfer and R\&D; however, it has been rare that the concept has been examined using a numerical dataset representing market performance, especially of resources and capabilities of companies using technology transfer, and resource-based theory. Moreover, this present research also applies the open innovation model to measure a firm's opening capability. The main purpose of this study is to find what kinds of abilities and capabilities can affect a firm's value.

This research employs data from the surveys provided by Korea Exchange and the Data Analysis, Retrieval, and Transfer System (a national database), using a sample of 215 enterprises in South Korea's mechanical, consumer, pharmaceutical, chemical, and IT \& semiconductor industries. This study explores firms' resources as a human resource, technology resource, fixed-asset resource, and governance structure (process) resource, as well as their capabilities as a searching capability, absorbing capability, and opening capability. The used method of analysis is the multiple regression model, where the dependent variable, financial performance (increased sales ratio), is a function of the moderating technology resource of the firm's innovative strategy. 


\section{Theoretical Backgrounds 2.I Technology Transfer}

Technology transfer is often referred to as a licensing, technological cooperation. Technology transfer is not only a simple way of trading technology, but it can also be a useful information source. Through technology transfer, a company can figure out its industry's market share and current status of technology development.

There are many definitions of technology transfer by various researchers. Foster (197I) refers to two different ways of technology transfer. Horizontal technology transfer is the transfer of technological knowledge or innovation between projects, organizations, industries, and nations. Vertical technology transfer is the transfer of technological knowledge or innovation, from basic to advanced research, for development through to commercialization. Camp and Sexton (1992) define technology transfer as the route of technological knowledge, ideas, and research results from the initial conceiving organization to the user organization, which focuses on licensing-in and technological cooperation. Both approaches to technology transfer involve acquiring innovation from an outside source as well as the sharing of technological knowledge for their products or processes. Therefore, Camp and Sexton's definition of technology transfer is based upon Foster's definition of horizontal technology transfer.

Technology transfer has three different types of technology cooperation. If a technology or innovation is acquired from an outside source, it is referred to as licensingin. Conversely, the selling or giving away technological knowledge to other companies is referred to as licensingout. Technology cooperation is not just a one-way but rather a bi-directional technology transfer. The three types of technology cooperation include cooperative R\&D, alliance, and joint-venture.

\section{I.I Licensing-in \& licensing-out}

Licensing-in is the acquiring of rights to other company's intellectual property. After a research result, such as a patent, is transferred to another company by a licensing contract, this acquired technology becomes a product and then commercialized (Parker and Zilberman, 1993; Parker et al., 1998; Thursby and Thursby, 2000). Licen- sing-in has many positive effects. It can be advantageous for decreasing expenditure of intellectual property management. If a firm does not have a basic patent, licensingin can be a great way to obtain a technology and avoid patent trouble with the basic patent owner. It can also be beneficial to build a good relationship with the patent providing company as a strategic partner. The main reasons for licensing-in by a firm are to enhance technology, solve patent problems, and/or start a new business for the regional market.

If a company has a competitive technology, then it can be another source of sales. Licensing-out is common way to sell a one's own technology to other firms. It is also good for strategic alliance, cross licensing, and entry to another market. Technology unused by one firm may be useful to another firm; therefore, licensing-out can be a source of income. Licensing-out strategy can create new business relationships with other companies, and the initial payment and royalty will increase a firm's income. Sometimes, licensing-out firms provide their technologies to universities for free in order to support the universities' R\&D activities and to facilitate cooperation with them.

\subsubsection{Technological cooperation}

Strategic alliance is defined as an exchange of resources, co-ownership, and active cooperative relationship between related companies. There are connected by different kinds of capital, technology, and various resources (Gulati \& Singh, 1998). The motive for strategic alliance is to affect the economics of scale and scope through coR\&D, co-manufacturing, and co-purchasing. Sharing complementary resources and capabilities between companies increases productivity, market power, and learning effect. Many companies nowadays use strategic alliance for these various purposes (Gulati \& Singh, 1998; Hagedoorn, 1993; Powell, 1996; Stuart, 2000).

\subsubsection{Previous studies}

Dunning's eclectic theory $(1977,1979)$ explains how to enter the global market by outlining three categories of advantages for a successful entry into the global market: ownership advantage, internalization advantage, and locational advantage. Ownership advantage, or firm specific advantage, allows a firm to overcome its disadvantage in 
the global market. If a firm has internalization advantage, it will keep the technology rather than selling it to another firm. Locational advantage gives power to a specific foreign location more than to the domestic location. If a firm has all three advantages, then they will invest in another country directly. If a firm only has firm specific advantage, it will choose to do indirect licensing. However, if a firm has firm specific advantage and internalization advantage, then they will only export technologies.

According to Dunning's classification, firm-specific advantage is an important factor in licensing. This present research will focus on firm-specific advantage for empirical analysis. Firm specificadvantagemainlyinvolves an intangible asset not owned by other firms. The characteristics of technology innovation, level of product differentiation, economy of product scale, technology intensity of products and process, input factor, and advantages to the market are all factors of firm-specific advantage (Euh, 1996).

Global companies have interest in transferring their technologies to developing countries. It can be the first step in creating a new source benefit and profit for the developing countries. Mottner and Johnson (2000) have studied why global companies choose licensing over direct investment, and the risk of licensing. Also, Tihanyi and Roath (2002) claim that providing an institutional environment related technology for developing countries is important.

Reddy \& Zhao (1990) refer to the factors of effective technology transfer, experiences between contractors, a competitive technological level of provider, efforts, supports, and organization of provider, the ability of absorbing technology and level of technology of innovator (this research will refer to the party receiving the technology as innovator hereinafter), characteristics of innovator, and the different types of technology transfer, licensing-in/-out and capital investment. It includes the relationship between provider and innovator, and technology training agreement. Cobb (1992) advises to get rid of resistance factors, organizational and legal, and regulations for successful technology transfer and to continue dynamic efforts between provider and innovator. He also suggests making an office of technology transfer and to have a lawyer available to the office of technology transfer staff.

Selecting a partner is a very important issue for strategic alliance. Many studies that have examined a partner's characteristics of strategic alliance claim that selecting a partner is very difficult, yet it is the key to success for alliance (Hitt, 1995; Hitt, 2000). There are two different approaches in selecting a partner. The first approach, the resource-based approach, entails determining what resources encompass a firm's capability, and the second approach involves the learning effect. The main criterion of selecting a partner based upon the resource-based approach is to determine the resource characteristics of firms and needs of new resources. Additionally, the main reason for the strategic alliance is resource characteristics of partner firms (Dussauge, 2000; Hitt, 1995; Kogut. 1988). This present research is different from the previous studies in that it focuses on the characteristics of the innovator and not on the provider.

Dyer (1998) and Stuart (1988) have studied the relationship characteristics between alliance partners, including the effects of the relative position and reputation of each partner firm, the strategic similarity of the firms, and their former relationship. Technology transfer strategy is constituted in three ways: licensing-in, licensing-out, and technological cooperation. This present research examines a firm's performance by external innovation. Therefore, because a firm gains financial profit from licensing-out from the contract deposit and licensing royalty, this present study will only examine licensing-in and technological cooperation strategies.

\subsection{Resource-Based View}

Resource-based theory suggests that firm resources and capabilities influence the growth and performance of the firm (Penrose, 1959; Barney, 1991; Mahoney and Pandian, 1992). The firm is defined as a set of productive resources and administrative organization (Penrose, 1959). Distinctive resources and capabilities make a firm competitive and robust.

The main question concerning the resource-based theory when it was first introduced was what characteristics of resources can generate sustained competitive advantages. Another question is why firms perform differently even in the same industry. There are four indicators of firm resources necessary to achieve sustained competitive advantage as suggested by Barney (1991). 
Valuable resources - Firm resources can be a source of competitive advantage when it is valuable. Resources are valuable when it is able to carry out the strategies to improve the firm's competence and performance. For example, if resources have the effect of reducing a firm's costs or increasing its revenues, those resources can be regarded as valuable resources.

Rare resources - Firm resources possessed by many competing or potentially competing firms cannot be sources of competitive advantage. A firm may have a competitive advantage when it is carrying out a valuable strategy not concurrently implemented by other firms.

Inimitable resources - Valuable and rare resources can be sources of maintained competitive advantage if other firms cannot easily get these resources. Several factors, such as a firm's history, implicit knowledge, and interconnection among resources, may increase inimitability of resources.

Non-substitutable resources - Firm resources that do not have strategically same resources are considered to be nonsubstitutable resources. If other firms have the same resources, the firms can carry out the same strategies in different ways using different resources. A firm may obtain sustained competitive advantage when other firms may not have the same competitive advantage using different resources.

Using these basic concepts of firm resources, empirical studies have examined resource-based theory in various contexts. There have been several research studies on technology transfer related to the resource-based theory, but there are not enough empirical studies on adjusting resources, as well as capabilities, for measuring firm performance since technological contracts are usually confidential. Thus, technology transfer information is hard to obtain from the market. This study uses the resourcebased theory for measuring firm performance. Figure I shows the concept of this research.

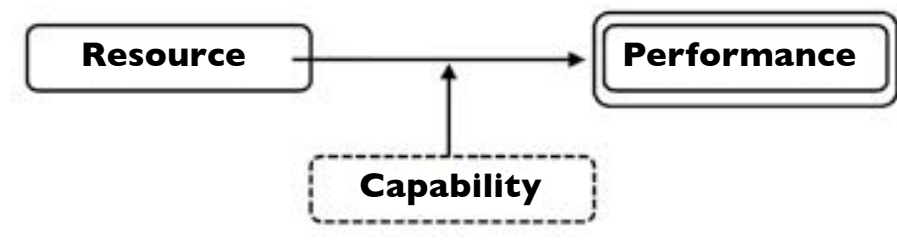

Figure I. Concept of this research
While the resource-based theory has been accepted as a 'theory' by some scholars (e.g. Conner, 1991; Grant, 1991; Conner and Prahalad, 1996), it is still usually considered to be a 'view'. It is perhaps because the resourcebased theory has not answered the two questions that are believed to be requisites to be a theory of the firm. The questions are: "Why do firms exist?" and "How is the boundary of the firm determined?" Priem and Butler (200I) argue that the resource-based "view" does not explain the key issues that should be addressed.

While Priem and Butler's (200I) argument claims that a theory of the firm should clearly explain the issues of firm existence and firm boundary decisions, Mahoney (200l) argues that even when a theory of the firm does not explain the existence of the firm, if it shows why the firm exist, it can be a theory of the firm. Mahoney (200I) considers the resource-based theory as a theory of the existence of the firm.

Indeed, scholars who agree with the knowledge-based view of the firm argue that the existence of the firm can be explained by using resource-based perspectives, even without the assumption of opportunism (Connor, 1991; Kogut and Zander, 1992; Grant, 1996). According to this view, the firm exists because the cost of knowledge transfer within the firm is lower than in the market. Teece (1977) is probably the first scholar who raised the issue of the cost of knowledge transfer. In his study on technology transfer by multinational firms, Teece (1977) has found several factors, such as transferee's experience and the capability knowledge, affect the cost of knowledge transfer. His finding is important because he empirically shows that knowledge transfer is not costless, as Arrow (1969) suggests. This idea about the cost difference in knowledge transfer is used to explain the existence of the firm. Conner (199I) argues that the firm exists because of the firm has advantages over market contracts in the efficiency of knowledge transplantation.

The effect of technological resources to a firm's value can be explained in two ways. First, as a direct effect, it affects a firm's value directly by technological resources as a means of advantages. This effect is called direct assets effects as well as efficiency effect. According to direct effect, if the firm has more valuable technological resources, then its competitiveness will increase. Second, as an indirect effect, it will indirectly affect firm's competitiveness and efficiency. Indirect effect is a mixture effect 
by two strategies, low cost strategy and differentiation strategy. Low cost strategy can be adopted by a productive process using competitive technological resources, whereas differentiation strategy makes a firm's ability by product innovation of manufacturing development (Meta et al., 1995; Spanos and Lioukas, 200I).

While the resource-based theory has been accepted as a 'theory' by some scholars (e.g. Conner, 1991; Grant, 1991; Conner and Prahalad, 1996), it is still usually considered to be a 'view'. It is perhaps because the resourcebased theory has not answered the two questions that are believed to be requisites to be a theory of the firm. The questions are: "Why do firms exist?" and "How is the boundary of the firm determined?" Priem and Butler (200I) argue that the resource-based "view" does not explain the key issues that should be addressed.

While Priem and Butler's (200I) argument claims that a theory of the firm should clearly explain the issues of firm existence and firm boundary decisions, Mahoney (200I) argues that even when a theory of the firm does not explain the existence of the firm, if it shows why the firm exist, it can be a theory of the firm. Mahoney (200I) considers the resource-based theory as a theory of the existence of the firm.

Indeed, scholars who agree with the knowledge-based view of the firm argue that the existence of the firm can be explained by using resource-based perspectives, even without the assumption of opportunism (Connor, 1991; Kogut and Zander, 1992; Grant, 1996). According to this view, the firm exists because the cost of knowledge transfer within the firm is lower than in the market. Teece (1977) is probably the first scholar who raised the issue of the cost of knowledge transfer. In his study on technology transfer by multinational firms, Teece (1977) has found several factors, such as transferee's experience and the capability knowledge, affect the cost of knowledge transfer. His finding is important because he empirically shows that knowledge transfer is not costless, as Arrow (1969) suggests. This idea about the cost difference in knowledge transfer is used to explain the existence of the firm. Conner (1991) argues that the firm exists because of the firm has advantages over market contracts in the efficiency of knowledge transplantation.

The effect of technological resources to a firm's value can be explained in two ways. First, as a direct effect, it affects a firm's value directly by technological resources as a means of advantages. This effect is called direct assets effects as well as efficiency effect. According to direct effect, if the firm has more valuable technological resources, then its competitiveness will increase. Second, as an indirect effect, it will indirectly affect firm's competitiveness and efficiency. Indirect effect is a mixture effect by two strategies, low cost strategy and differentiation strategy. Low cost strategy can be adopted by a productive process using competitive technological resources, whereas differentiation strategy makes a firm's ability by product innovation of manufacturing development (Meta et al., 1995; Spanos and Lioukas, 200I).

\subsection{Open Innovation Model}

Chesbrough suggests that there is a strong movement among many of today's firms toward an "open innovation" model, which refers to the use of external sources and actors to achieve innovation (Chesbrough, 2003). At the same time, many empirical studies have proven that internal search efforts can significantly influence innovative performance (Katila, 2002; Katila and Ahuja, 2002). In this present study, the open innovation concept is included in the capabilities category. Companies that have more openness tendency will acquire more innovations from outside sources. In addition, those companies will outsource their own R\&D that is not a core technology of the firm. The searching and opening capabilities are adopted into the open innovation model concept.

An example of an open innovation strategy can be seen in the research and development model of Proctor \& Gamble. To ensure its R\&D effectiveness, Proctor \& Gamble has used a "connect and develop" (C\&D) model, which is a strategy of exploiting external ideas and actors. Sakkab finds this C\&D model more effective than an internally focused R\&D strategy (Sakkab, 2002; John \& Peter, 2003).

The role that networks and linkages play in innovation involves a popular subject of research. Many studies show that today's innovators are employ an innovative system where they rely on interactions with users, suppliers, and wide range of institutions (Hippel, 1988; Lundvall, 1992; Brown and Eisenhardt, 1995; Szulanski, 1996). In other words, today's innovators rarely innovate alone. They tend to work together in teams or unions based on trust built in communities of practice, and are embedded in a solid network of interactions (Scott and Brown, 1999; Brown and Duguid, 2000).

As a recent example of research regarding the interactive, 
distributive, and open nature of innovation, this present research considers Chesbrough's proposed "open innovation" model (Chesbrough, 2003; Chesbrough, 2003). He suggests that the advantages firms gain from internal R\&D expenditure have declined, and that, accordingly, many innovative firms now spend little on R\&D and yet are able to successfully innovate by drawing on worldwide knowledge and expertise; such firms also commercialize external ideas by deploying outside pathways to the market (Chesbrough, 2003). Many empirical studies have commented on the effectiveness and adoption of the open innovation model (Vrande, et al., 2006; West and Gallagher, 2006).

The focus on openness and interaction in innovation studies reflects a wider research trend, that is, many studies on the behavior of firms suggest that the network of relationships existing among firms and the external environment can play an important role in shaping performance. For instance, Rosenkopf and Nerkar explored the role of boundary-spanning searches (Rosenkopf and Nerkar, 200I). They found that both organizational and technological boundaries inhibit subsequent technological evolution, and that the impact of explorative search is greatest when the search spans both organizational and technological boundaries. Meanwhile, another study investigated inter-organizational collaboration in the field of biotechnology, and assessed the contribution of collaboration to learning and performance (Powell, et al., 1996). They found that firms embedded in benefit-rich networks are likely to have greater innovative performance. Two other studies examined empirical research engaged in the open innovation model and innovative performance (Feams, et al., 2005; Nieto and Santamaria, 2007). In summary, all the aforementioned studies point to the importance of firms' open behavior in their search for innovative opportunities. These studies suggest that performance differences between organizations can be ascribed to such behavior.

\section{Hypotheses}

Resource-based theory emphasizes the importance of resource and capability of firms. For sustainable competitiveness, firms should have their own resources and capabilities that cannot be imitated by other firms. This firm-specific ability is important as well as the technological and managerial environment. Resources include financial assets, manufacturing equipment, brand name, technological knowledge, marketing knowhow, and managing skill of organization. Capabilities refer to special abilities of efficiently managing, utilizing, and increasing firm-specific resources.

The more firm-specific resources and capabilities a firm has, the more valuable the firm is than its competitors. Therefore, firms that have competitive resources can enter a new market easily. Using these resources and capabilities, firms have advantages in entering the market and gaining more profit (Dierickx and Cool, 1989; Wernerfelt, 1984; Barney, 1991). The research model is shown below.

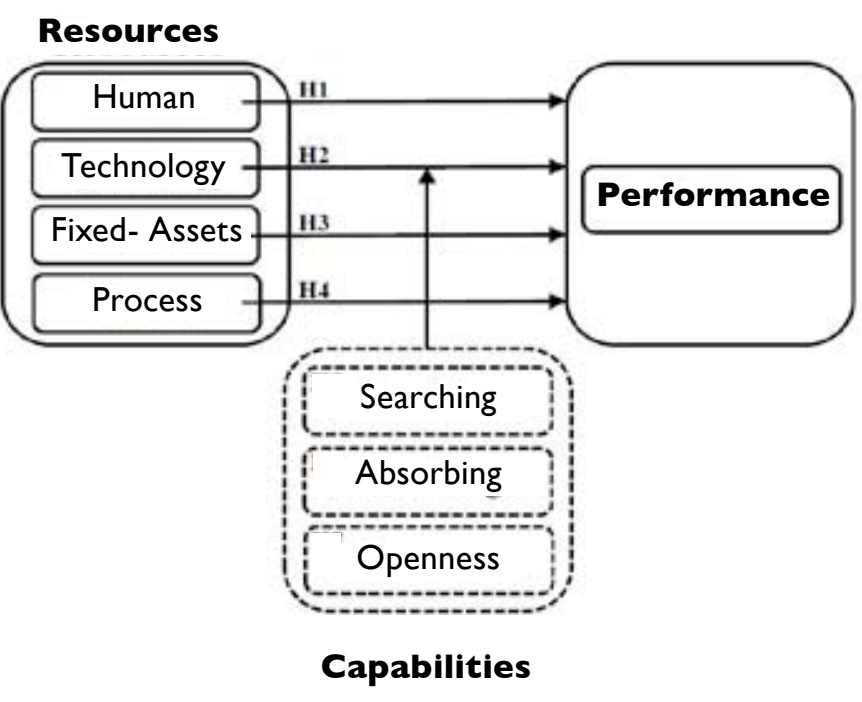

Figure 2. Research Model

\section{I Resources}

Intangible assets cannot be clearly defined because of its large scope and scale in various industry sectors. Grant (1991) defines intangible assets as technological capital, human capital, reputational capital, and organizational capital. Technological capital is an important element for a firm's competitive advantage as a knowledge-intensive intangible asset. Intangible assets are composed with tacit components, and thus it is hard to imitate and transfer. This high specificity and complexity makes it difficult to find a decision factor (Kogut and Zander, 1993).

Levy and Terleckyj (1983) examined the effects of firm's productivity by technology innovation. They measured technology innovation efforts by the number of patents, R\&D intensity per sales, and R\&D human resource ratio. These variables related positively to firm's productivity. 
Taking into account the difficulty in gathering information about the number of R\&D employees, this present research will use human resource as a ratio of all number of employees and firm's fixed-assets. If a firm's human resource variable is larger than other firms, then they will share and generate innovative ideas more than other firms.

Hypothesis I: Human resource relates positively to financial performance.

Research and development are main drivers for economic growth. A firm's technological advance is a result of $R \& D$ investment efforts. R\&D expenditure is the expense used for making new products and services, and investigating the market. Many technology based firms use large R\&D expenditure to satisfy customers and to make new products. R\&D expenditure is used for product improvement as well as process improvement.

Hirschey and Weygandt (1985) studied the effects of R\&D activities in the capital market. They found that R\&D investment relates positively to capital market. Chan et al. (1990) examined 96 listed companies to compare their R\&D activities with their firm's value from 1979 to 1989. R\&D expenditures relate positively to the firm's value. They point out that this phenomenon happens more in the high technology industry. Szewczyk et al. (1996) also claims R\&D activities relate positively to the value of the firm from his data of 252 companies from 1979 to 1992. They propose that principle positive factors are R\&D expenditure, liabilities ratio, and public investor's stock ratio.

Hypothesis 2: Technology resource relates positively to financial performance.

Intangible assets are important to a firm's innovative capacity. However, if there are not enough tangible assets to make products for innovation, it is impossible to make a profit. Therefore, basic manufacturing process and equipment will enhance a firm's value. This study adopts fixed-assets as tangible assets. Kim and Lyn (1987) measured fixedassets as capital intensity, ratio of fixed-assets and sales.

Hypothesis 3: Fixed-assets relate positively to financial performance.

Alchian and Demsetz (1972) and Jensen and Meckling (1976) claim that if stock ratio of CEO is getting high, then R\&D activity for the future will increase because of the expectation of the compensation to CEO. Cho (1989) and Agrawal and Mandelker (1986) also assert that a firm's capital expenditure relates positively to CEO stock ratio.

Hypothesis 4: Stock possession ratio of special stockholders (i.e., family members or relatives) relates positively to business performance.

\subsection{Capabilities}

Qian (2002) found that a firm's globalization relates positively to sales ratio. He analyzed small and medium companies in the U.S. Many other studies show that internalization relates positively to a firm's value (Miller \& Pras, 1980; Buhner, 1987; Danniels \& Bracker, 1989; Geringer et al., 1989; Tallman \& Li, 1996; Qian, 2002). Ramsawamy (1993) used the number of branches abroad as a determinant of internalization level. Contractor et al. (2003), on the other hand, applied mixture index for measuring internalization. Mixture index is composed of foreign sales ratio, foreign employee ratio, and ratio of foreign branches.

Hypothesis 5: The searching capability of technology relates positively to firm's financial performance.

Branch (1974) examined the relationship between firm benefit and R\&D expenditure. He claims that current R\&D expenditure relates positively to a firm's future cash flows. He used the number of patents as the firm's R\&D variable to examine the accounting profit ratio by a multiple regression model. Levy and Terleckyj (1983) found that new product development and technology innovation is related to firm productivity. They used the number of patents, R\&D expenditure ratio per sales, and R\&D employees ratio as independent variables. This present research confirms that the number of patents, R\&D intensity, and R\&D human resource relates positively to firm productivity from $2.0 \%$ to $2.4 \%$. In this present stu$\mathrm{dy}$, the firm's absorbing research variable is calculated by the number of existing patent applications since the two years from the event date of technology transfer.

Hypothesis 6: The absorbing capability of technology relates positively to firm's financial performance.

Feams, Looy, and Debackere examined the relationship between openness and innovative performance in the Belgian manufacturing sector, while Nieto and Santama- 
ria surveyed Spain's manufacturing industry (Feams and Looy, 2005; Nieto and Santamaria, 2007). These two empirical studies found that a firm's openness, in terms of its innovating procedures, is related positively to its innovative performance. However, both studies used an all perceptual data set. The variables used in this present study are adopted from these previous researches as control variables. The new variable of openness is the $R \& D$ outsourcing ratio.

Hypothesis 7: The opening capability on technology relates positively to firm's financial performance.

\section{Data and Descriptive Statistics}

\section{I Data}

The data for the analysis were drawn from three different sources. The first is the Korea Exchange (KRX) which was created through the integration of the three existing Korean spot \& futures exchanges, Korea Stock Exchange, Korea Futures Exchange, and KOSDAQ (Korea Securities Dealers Automated Quotations), under the Korea Stock \& Futures Exchange Act. The securities and future markets of former exchanges are now operated as business divisions of the KRX including the Stock Market Division, KOSDAQ Market Division, and Derivatives Market Division. As of November 2009, the KRX had over 1,700 listed companies with a combined market capitalization of over $\$$ I trillion. It had normal trading sessions from 09:00am to 03:00pm on all days of the week except Saturdays, Sundays and holidays declared in advance. The KRX database shows which firms have received a warning and the industry sector of the listed company, KOSPI (Korea Composite Stock Price Index by the Stock Market Division) or KOSDAQ. Since the requisite to be listed under KOSDAQ is less strict than KOSPI, small and medium companies are usually listed under KOSDAQ.

The second database source is from the Data Analysis, Retrieval, and Transfer System (DART) in South Korea. This is an electronic disclosure system that allows companies to submit disclosures online, in which such disclosures immediately become available to investors and other users. This disclosure includes firm's financial statements, public announcements (especially pertaining to technology transfer and obtaining patents), and other important information for stock holders. This present study gathered data mainly from financial statements and technology transfer announcements. Financial statements reveal a firm's assets, sales, number of employees, R\&D expenditure, and their status of share holder and foreign branches. This data is very useful for analyzing of resources and capability of firm.

The Worldwide Intellectual Property Search (WIPS), an intellectual property information service company in South Korea, is one of the most important data sources for patents. It offers worldwide patent search online, a patent information search, and an analysis consulting service. WIPS service provides the international IP community (Korea, US, Japan, European Patent, WIPO PCT Publications, Global Patent, International Patent Document Center, and China) with access to over 100 million patent records.

From a total sample of 782 events of technology transfer and cooperation from 1999 to 2009, the first subsample of 576 events was chosen after excluding companies listed before $200 \mathrm{I}$ and after 2008. This first subsample was used for overall status of technology transfer and cooperation. The second subsample of $36 \mathrm{I}$ events was selected after excluding poor-condition firms and licensing-out firms.

\subsection{Descriptive Statistics}

Figure 3 shows the change in the number of licensing-in from 2001 to 2008 in South Korea. The number is decreasing as time passes. KOSDAQ companies tend to have more licensing-in than KOSPI companies. This may be attributed by the fact that small and medium companies listed their stocks under KOSDAQ. This graph shows that SMEs use licensing-in strategy more than large companies because of their insufficient resources. For the same reason, large companies which have more resources and capabilities tend to license-out to other companies. Figure 4 indicates KOSPI companies have a greater number of licensing-out except in year 2002. The number of licensing-in decreased and the number of licensing-out maintained, which means that the ability of technology in South Korea increased. Technological cooperation graph of Figure 5 also shows the similar tendency of licensing-out. 

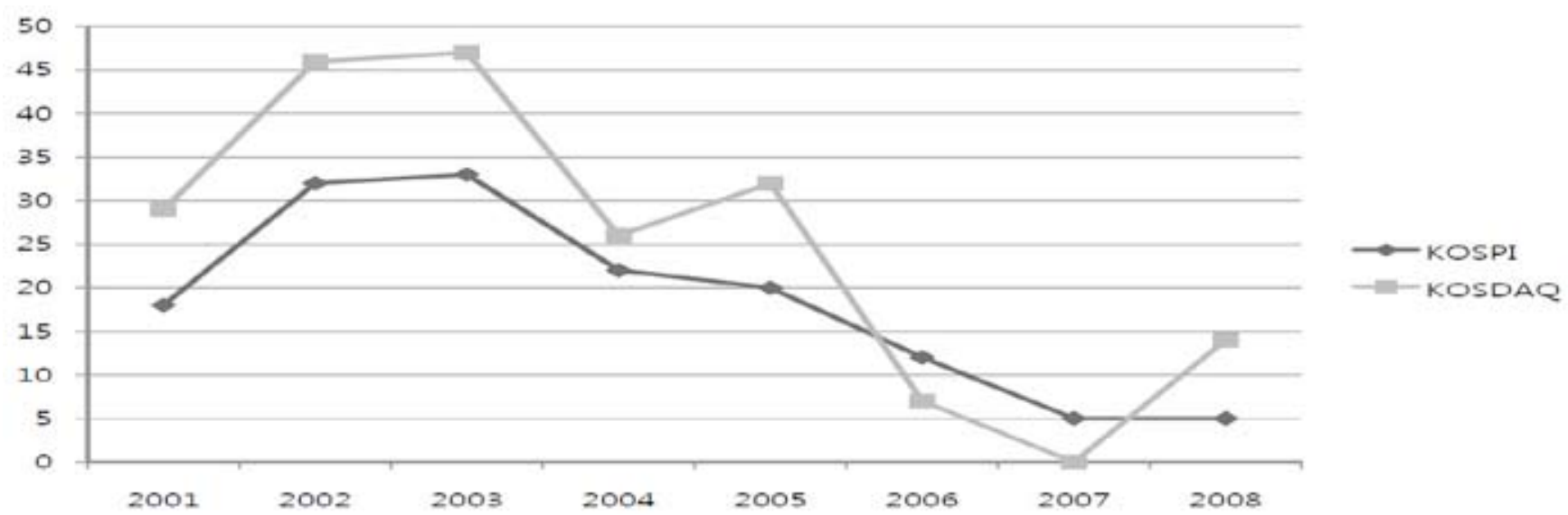

Figure 3. Licensing-In

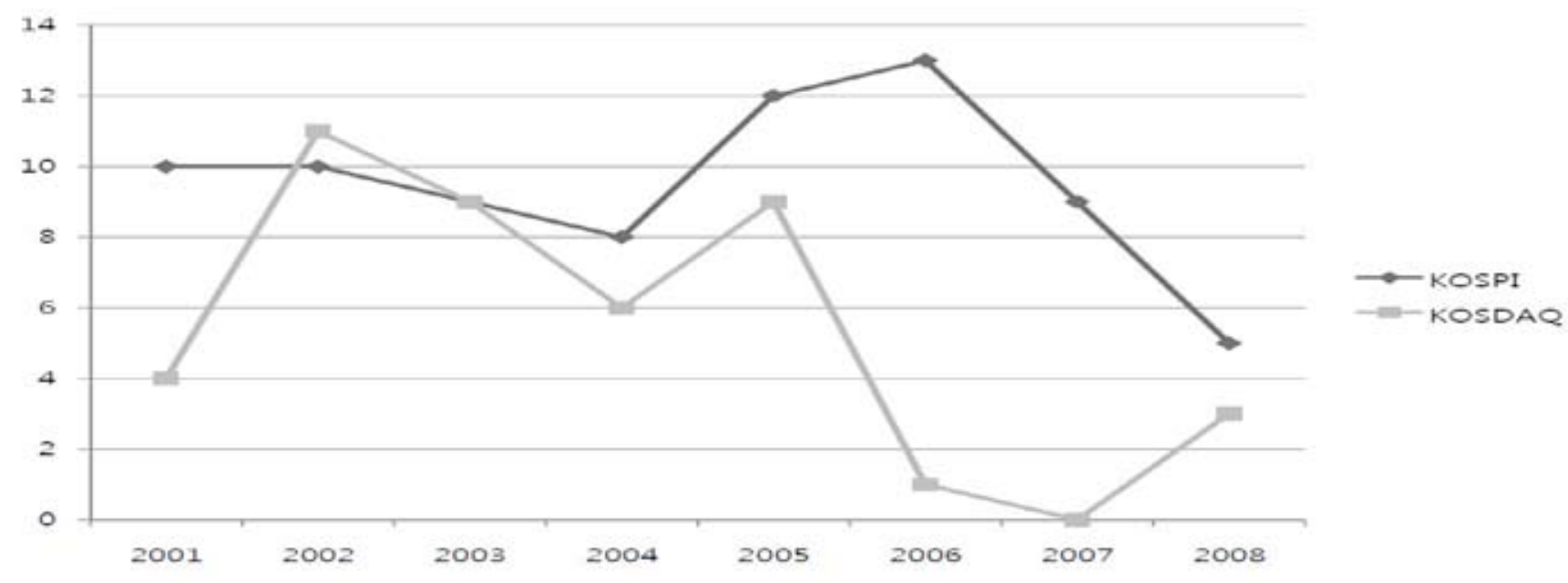

Figure 4. Licensing-Out

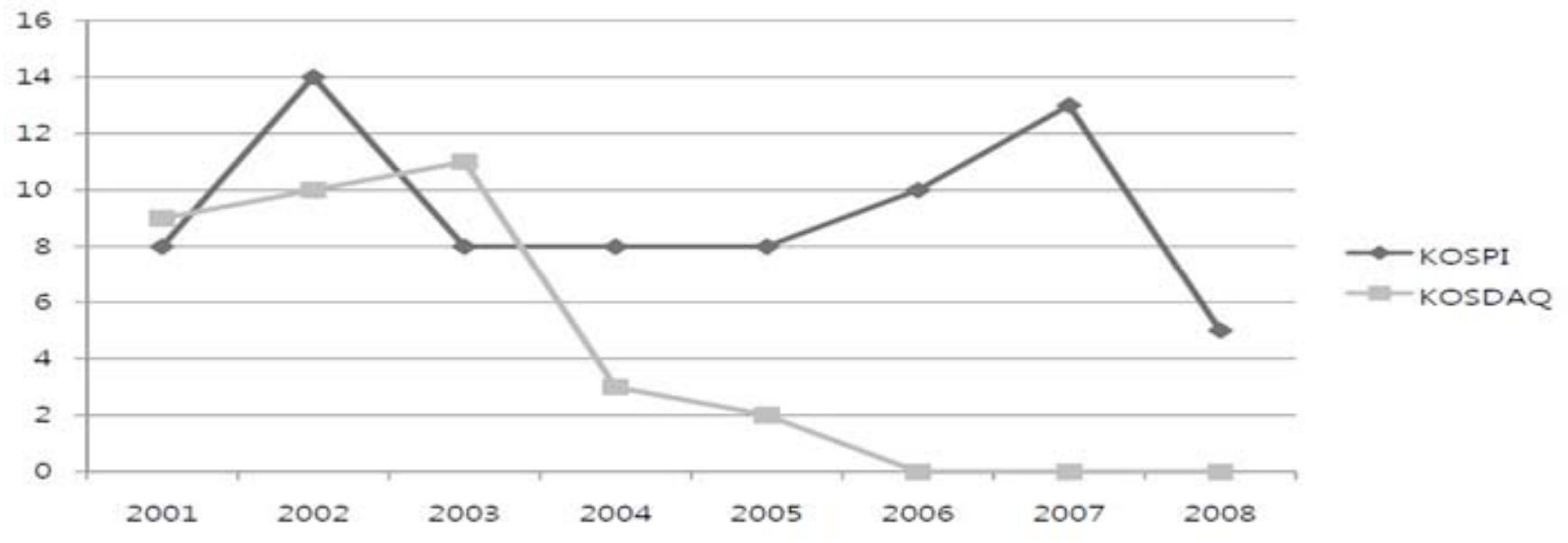

Figure 5. Technological Cooperation 
Table I displays the descriptive results of the number of firms, means, standard deviations, and the minimums and maximums of each type of variable. This overview is important in understanding the characteristics of each industry being evaluated.

In terms of human resource, the pharmaceutical sector is the highest ranked, while the chemical sector is the lowest ranked. The IT \& semiconductor industry has a very high technology resource. This serves as evidence that IT \& semiconductor companies tend to spend a lot of money on R\&D, a reflection of the fact that South Korea is home to major semiconductor companies such as Samsung and Hynix. The pharmaceutical industry has a high level of fixed-assets resource. In terms of capabilities, the pharmaceutical industry is the highest ranked on absorbing and opening capability. This serves as evidence that the pharmaceutical sector tend to conduct self-R\&D and outsource. The mechanical industry is the highest ranked in the searching capability. 


\begin{tabular}{|c|c|c|c|c|c|c|}
\hline & Type & $\begin{array}{l}\text { No. of } \\
\text { firms }\end{array}$ & Means & S.D. & Min & $\operatorname{Max}$ \\
\hline Capital & & 361 & 2177577 & 10619268 & 4924 & 65225252 \\
\hline Number of employees & & 361 & 3162 & 14448 & 13 & 85813 \\
\hline \multirow{6}{*}{$\begin{array}{l}\text { Human } \\
\left(X_{1000)}\right.\end{array}$} & & 361 & 9.73 & 9.11 & 0.36 & 88.52 \\
\hline & Mechanical & 82 & 9.74 & 5.43 & 1.31 & 23.10 \\
\hline & Consumer & 51 & 10.75 & 16.68 & 1.57 & 88.52 \\
\hline & Chemical & 56 & 6.25 & 4.43 & 0.99 & 21.59 \\
\hline & Pharmaceutical & 54 & 11.53 & 7.00 & 1.97 & 27.82 \\
\hline & IT \& Semiconductor & 118 & 10.12 & 8.75 & 0.36 & 52.72 \\
\hline \multirow{6}{*}{$\begin{array}{l}\text { Technology } \\
\left(X_{100)}\right.\end{array}$} & & 361 & 6.64 & 9.33 & 0.01 & 53.44 \\
\hline & Mechanical & 82 & 5.35 & 7.26 & 0.05 & 42.85 \\
\hline & Consumer & 51 & 6.47 & 12.58 & 0.01 & 53.44 \\
\hline & Chemical & 56 & 1.76 & 1.66 & 0.10 & 6.20 \\
\hline & Pharmaceutical & 54 & 6.70 & 9.77 & 0.84 & 49.29 \\
\hline & IT \& Semiconductor & 118 & 9.91 & 9.77 & 0.08 & 42.85 \\
\hline \multirow{6}{*}{$\begin{array}{l}\text { Fixed-assets } \\
(\mathrm{X} 10)\end{array}$} & & 361 & 7.44 & 9.65 & 0.59 & 90.34 \\
\hline & Mechanical & 82 & 6.10 & 6.57 & 1.99 & 45.14 \\
\hline & Consumer & 51 & 9.95 & 15.17 & 0.59 & 65.67 \\
\hline & Chemical & 56 & 7.17 & 8.61 & 1.63 & 49.33 \\
\hline & Pharmaceutical & 54 & 8.90 & 9.20 & 2.11 & 44.72 \\
\hline & IT \& Semiconductor & 118 & 6.74 & 8.91 & 0.90 & 90.34 \\
\hline \multirow[t]{6}{*}{ Process } & & 361 & 37.12 & 15.98 & 5.50 & 80.00 \\
\hline & Mechanical & 82 & 43.66 & 16.43 & 5.00 & 80.00 \\
\hline & Consumer & 51 & 40.23 & 14.48 & 6.30 & 72.80 \\
\hline & Chemical & 56 & 41.31 & 15.23 & 11.34 & 70.62 \\
\hline & Pharmaceutical & 54 & 34.08 & 15.94 & 10.67 & 70.50 \\
\hline & IT \& Semiconductor & 118 & 30.64 & 14.01 & 10.53 & 65.01 \\
\hline \multirow[t]{6}{*}{ Searching } & & 361 & 0.69 & 0.46 & 0 & 1 \\
\hline & Mechanical & 82 & 0.79 & 0.41 & 0 & 1 \\
\hline & Consumer & 51 & 0.78 & 0.42 & 0 & 1 \\
\hline & Chemical & 56 & 0.52 & 0.50 & 0 & 1 \\
\hline & Pharmaceutical & 54 & 0.56 & 0.50 & 0 & 1 \\
\hline & IT \& Semiconductor & 118 & 0.73 & 0.45 & 0 & 1 \\
\hline \multirow[t]{6}{*}{ Absorbing } & & 361 & 0.67 & 0.47 & 0 & 1 \\
\hline & Mechanical & 82 & 0.76 & 0.43 & 0 & 1 \\
\hline & Consumer & 51 & 0.24 & 0.43 & 0 & 1 \\
\hline & Chemical & 56 & 0.82 & 0.39 & 0 & 1 \\
\hline & Pharmaceutical & 54 & 0.85 & 0.36 & 0 & 1 \\
\hline & IT \& Semiconductor & 118 & 0.64 & 0.48 & 0 & 1 \\
\hline \multirow[t]{6}{*}{ Openness } & & 361 & 0.10 & 0.18 & 0 & 1 \\
\hline & Mechanical & 82 & 0.04 & 0.11 & 0 & 1 \\
\hline & Consumer & 51 & 0.11 & 0.22 & 0 & 1 \\
\hline & Chemical & 56 & 0.06 & 0.18 & 0 & 1 \\
\hline & Pharmaceutical & 54 & 0.22 & 0.23 & 0 & 0.73 \\
\hline & IT \& Semiconductor & 118 & 0.09 & 0.16 & 0 & 1 \\
\hline Increased sales ratio & & 361 & 0.16 & 0.41 & -0.88 & 2.58 \\
\hline
\end{tabular}

Table I. Descriptive Statistics 


\section{Model}

\section{I Dependent Variable}

For measuring a firm's performance, this research considers the increased sales ratio. There are many variables to measure the value of firms, including sales ratio, net profit, and stock price at a certain date. Lee et al. (1998) uses the sales ratio compared with the next year to measure the venture company's performance. He calculates the change ratio of performance during the 18 months after the date of cooperation. Coviello and Munro's (1995) research on the relationship of firm internationalization and performance also uses the increased sales ratio to measure firm growth as a dependent variable. Sougiannis (1994) found that R\&D activity relates positively to a firm value, especially when a firm value reaches its peak after 3 years since the initial R\&D. This present study measures increased sales ratio as a performance of the firm between the event year and the next year. Following Sougiannis' research, this study modified the dependent variable to 2 years increased sales ratio, under the assumption that the performance of technology transfer will have a faster return benefit than self-R\&D activity.

\subsection{Independent Variables}

This present research uses four variables as determinants of resources. Intangible assets cannot be clearly defined because of its large scope and scale in various industry sectors. Grant (1991) defines intangible assets as technological capital, human capital, reputational capital, and organizational capital. Intangible assets are composed of tacit components, thus making it difficult to imitate and transfer. This high specificity and complexity makes it difficult to find a decision factor (Kogut and Zander, 1993). Levy and Terleckyj (1983) examined the effects of firm productivity by technology innovation. They measured technology innovation efforts by the number of patents, R\&D intensity per sales, R\&D human resource ratio. These variables relate positively to firm productivity. Because of the difficulty in gathering information about the number of R\&D employees, this research considers the human resource as the ratio of all number of employees and firm's fixed-assets. If the human resource ratio is larger than other variable ratios, there will be an increase in sharing and generating innovative ideas.
Cohen and Klepper found that research and development activity relates positively to firm performance (Cohen and Klepper, 1996). Baldwin and Hanel found that R\&Dintense companies received a net profit per sales raise of $63 \%$ (Baldwin and Hanel, 2003). R\&D intensity is used as a technology resource variable. Technology is calculated by dividing total R\&D expenditure by sales. Fixedassets ratio is defined as the ratio between fixed-assets and sales. Kim and Lyn (1987) adopted fixed-assets ratio as the capital intensity. Process is defined as the special stockholder's stock possession ratio. A special stockholder is a family member or relative. Alchian and Demsetz (1972) and Jensen and Meckling (1976) claim that if stock ratio of CEO increases, then R\&D activity for the future will increase because of the growth in compensation and firm's market value. Cho (1989) and Agrawal and MandeIker (1986) assert that firm's capital expenditure relates positively to CEO stock ratio.

Determinants of capabilities consist of three variables. Searching capability is a dummy variable; it takes the value of $\mathrm{I}$ if the firm has a branch or R\&D center in a foreign country, otherwise it takes the value of 0 . Ramsawamy (1993) and Contractor et al. (2003) used the number of branches in foreign countries to measure the internationalization level. Absorbing capability is defined as the number of existing application of patents for 2 years from the event date. Many studies have used patent information to measure and analyze technological innovation and firm performance (Albert et al., 1990; Brockhoff, 1992; Harshoff et al., 1999; Pilkington, 2004). Openness is defined as R\&D outsourcing value divided by R\&D expenditure. If one looks at the category of R\&D activity on each company's report on DART, one can find the amount of outsourcing fee with other numbers of R\&D expenditure. Meanwhile, openness value is total R\&D expenditure divided by outsourcing fee. It refers to the size and value of R\&D outsourcing, or how dependent the company is on others for its R\&D.

\subsection{Control Variables}

The size of firms is a typical variable in studies of innovation because larger firms have greater ability and strategic freedom than smaller firms (Hagedoorn and Duysters, 
2002). Company size is measured by two variables: capital and number of employees. Capital is the number of total capital in the event year, while the number of employees refers to the company's roster of full-time employees (Yeoh and Roth, 1999). In addition, this study uses five dummy variables for the industry type to indicate whether the firms belong to the mechanical, consumer, pharmaceutical, chemical, and IT \& Semiconductor industry.

\section{Results}

Multiple regression analysis was used to test the hypotheses. In step I, the control variables were entered into the regression equation. In step 2 , both the control and independent variables of resources were entered. In step 3 , the control, resources variables and capabilities variables were entered. In step 4, the control, resources variables, capabilities variables, and the controlling effect variables (multiply 'technology' variable by each of capabilities variables) were entered. The effect of the human, technology, fixed-assets, and process were found in step 2. Step 4 asks for confirmation of the hypothesis of controling effects of capabilities (searching, absorbing, and openness) on technology resources.

The main analysis (Table 2) shows that the human, technology, and fixed-assets resources have a positive effect on business performance. Among the resource variables, technology and fixed-assets are highly significant. However, the process variable negatively affects the increased sales ratio.

On the other hand, the results for the capabilities variables suggest that the searching and absorbing variables can augment business performance, except for openness capability. The openness capability even shows a negative effect on firm performance, but the effect is not significant. This research used multiple variables to test a financial performance by capabilities, and assumed that three capabilities can affect the technology resource. The multiple variables are calculated by multiplying the technology resource variable by each of the three capabilities variables (searching, absorbing, and openness). The controlling effect of capabilites has a significant positive effect on firm value.

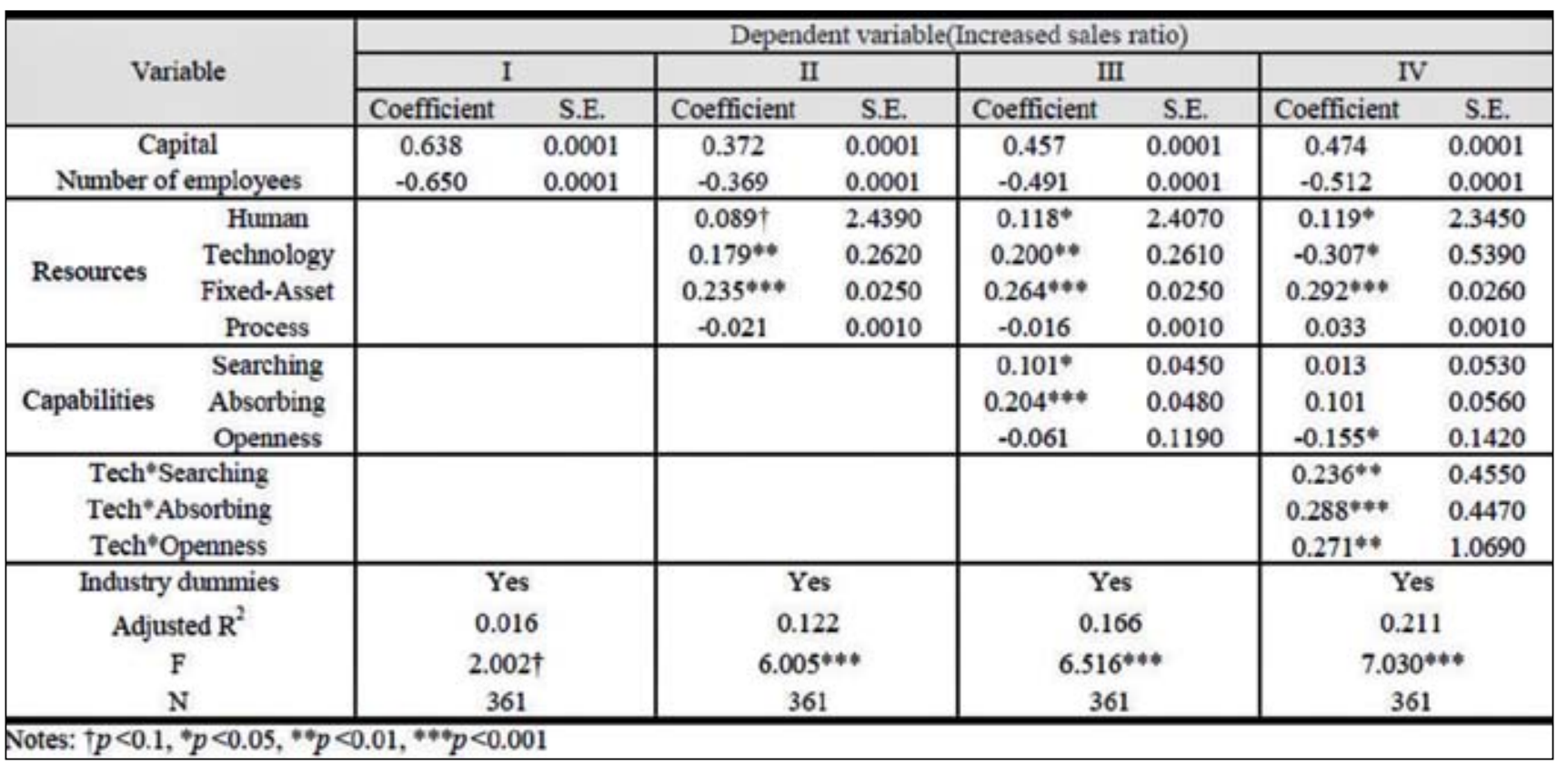

Table 2. Results of Regression Analysis (Total) 
The main analysis (Table 2) shows that the human, technology, and fixed-assets resources have a positive effect on business performance. Among the resource variables, technology and fixed-assets are highly significant. However, the process variable negatively affects the increased sales ratio.

On the other hand, the results for the capabilities variables suggest that the searching and absorbing variables can augment business performance, except for openness capability. The openness capability even shows a negative effect on firm performance, but the effect is not significant. This research used multiple variables to test a financial performance by capabilities, and assumed that three capabilities can affect the technology resource. The multiple variables are calculated by multiplying the technology resource variable by each of the three capabilities variables (searching, absorbing, and openness). The controlling effect of capabilites has a significant positive effect on firm value.

\begin{tabular}{|c|c|c|c|c|c|c|c|c|c|}
\hline \multirow{3}{*}{\multicolumn{2}{|c|}{ Variable }} & \multicolumn{8}{|c|}{ Dependent variable(Increased sales ratio) } \\
\hline & & \multicolumn{2}{|c|}{ I } & \multicolumn{2}{|c|}{ II } & \multicolumn{2}{|c|}{ III } & \multicolumn{2}{|c|}{ IV } \\
\hline & & Coefficient & S.E. & \multicolumn{2}{|c|}{$\frac{\text { II }}{\text { Coefficient }}$} & Coefficient & S.E. & \multirow{3}{*}{\begin{tabular}{|c|} 
Coefficient \\
$1.347 \dagger$ \\
$-1.598^{4}$
\end{tabular}} & \multirow{3}{*}{$\begin{array}{c}\frac{S . E .}{0.0001} \\
0.0001\end{array}$} \\
\hline & & $1.948^{*}$ & 0.0001 & $1.503^{*}$ & 0.0001 & $1.269 \dagger$ & 0.0001 & & \\
\hline Number o & employees & $-2.286^{* 4}$ & 0.0001 & $-1.730^{4}$ & 0.0001 & $-1.476^{*}$ & 0.0001 & & \\
\hline \multirow{4}{*}{ Resources } & Human & & & 0.111 & 2.2980 & $0.265^{* *}$ & 2.4440 & $0.233^{*}$ & 2.5630 \\
\hline & Technology & & & 0.118 & 0.2290 & $0.121 \dagger$ & 0.2170 & -0.111 & 1.7240 \\
\hline & Fixed-Asset & & & $0.407^{* 4 *}$ & 0.0430 & $0.503^{+4 *}$ & 0.0420 & $0.366^{* *}$ & 0.0560 \\
\hline & Process & & & $0.149 \dagger$ & 0.0010 & $0.142 \dagger$ & 0.0010 & $0.151 \dagger$ & 0.0010 \\
\hline \multirow{3}{*}{ Capabilities } & Searching & & & & & -0.027 & 0.0270 & $-0.154 \uparrow$ & 0.0340 \\
\hline & Absorbing & & & & & $0.366^{+4 *}$ & 0.0350 & $0.323^{\circ}$ & 0.0550 \\
\hline & Openness & & & & & $0.227 * *$ & 0.0790 & $0.315^{* *}$ & 0.1070 \\
\hline \multirow{3}{*}{\multicolumn{2}{|c|}{$\begin{array}{l}\text { Tech*Searching } \\
\text { Tech*Absorbing } \\
\text { Tech*Openness }\end{array}$}} & & & & & & & $0.277^{*}$ & 0.6000 \\
\hline & & & & & & & & 0.169 & 1.6900 \\
\hline & & & & & & & & -0.136 & 2.4920 \\
\hline \multicolumn{2}{|c|}{ Industry dummies } & \multicolumn{2}{|c|}{ Yes } & \multicolumn{2}{|c|}{ Yes } & \multicolumn{2}{|c|}{ Yes } & \multicolumn{2}{|c|}{ Yes } \\
\hline \multicolumn{2}{|c|}{ Adjusted $\mathrm{R}^{2}$} & \multicolumn{2}{|c|}{0.322} & \multicolumn{2}{|c|}{0.422} & \multicolumn{2}{|c|}{0.490} & \multicolumn{2}{|c|}{0.502} \\
\hline \multirow{2}{*}{\multicolumn{2}{|c|}{ F }} & \multicolumn{2}{|c|}{$12.935^{*+*}$} & \multicolumn{2}{|c|}{$12.018^{*+* *}$} & \multicolumn{2}{|c|}{$12.163^{* * *}$} & \multicolumn{2}{|c|}{$10.496^{* 4 *}$} \\
\hline & & \multicolumn{2}{|c|}{152} & \multicolumn{2}{|c|}{152} & \multicolumn{2}{|c|}{152} & \multicolumn{2}{|c|}{152} \\
\hline
\end{tabular}

Table 3. Results of Regression Analysis (Large Enterprise)

\begin{tabular}{|c|c|c|c|c|c|c|c|c|c|}
\hline & & & & Depen & at variabl & Increased sale & ratio) & & \\
\hline Va: & able & 1 & & 1 & & & & & \\
\hline & & Coefficient & S.E. & Coefficient & S.E. & Coefficient & S.E. & Coefficient & S.E. \\
\hline & & 0.040 & 0.0001 & 0.016 & 0.0001 & -0.077 & 0.0001 & -0.094 & 0.0001 \\
\hline Number o & employees & $-0.138+$ & 0.0010 & -0.006 & 0.0010 & -0.040 & 0.0010 & -0.008 & 0.0010 \\
\hline & Human & & & 0.081 & 3.7960 & 0.077 & 3.7110 & 0.080 & 3.6730 \\
\hline Rescurces & Technology & & & $0.201^{*}$ & 0.3840 & $0.186^{\circ}$ & 0.3820 & -0.189 & 0.7650 \\
\hline Resoures & Fixed-Asset & & & $0.190^{+}$ & 0.0350 & $0.223^{4+}$ & 0.0350 & $0.291^{* *}$ & 0.0360 \\
\hline & Process & & & -0.099 & 0.0020 & -0.066 & 0.0020 & -0.019 & 0.0020 \\
\hline & Searching & & & & & $0.184^{* *}$ & 0.0740 & 0.147 & 0.0970 \\
\hline Capabilities & Absorbing & & & & & $0.192^{4 *}$ & 0.0740 & 0.143 & 0.0930 \\
\hline & Openness & & & & & -0.090 & 0.1810 & $-0.222^{*}$ & 0.2310 \\
\hline Tech"s & arching & & & & & & & 0.111 & 0.6810 \\
\hline Tech*A & sorbing & & & & & & & $0.185 \dagger$ & 0.6240 \\
\hline Tech' $^{*}$ & penness & & & & & & & $0.323^{* *}$ & 1.5260 \\
\hline Industry & dummies & & & & & & & & \\
\hline Adju & $\operatorname{ted} \mathrm{R}^{2}$ & $0 . c$ & & 0.1 & & 0.1 & & & \\
\hline & & 2.7 & & 4.12 & & 4.64 & & 4.57 & \\
\hline & & 2 & & 2 & & & & & \\
\hline
\end{tabular}


The results of Table 3 and 4 show that there is a difference between SMEs (Small and Medium Enterprises) and Large Enterprises. In large enterprises, fixed-assets and the process variables have a significant positive effect on the increased sales ratio. In SMEs, technology and fixed- assets variables have a significant positive effect on the value of firms. Regarding the controlling effect, there are clear differences. The searching capability on technology is more important to large companies than to SMEs. Absorbing and openness capabilities have a positive controlling effect on the performance significantly on SMEs.

\begin{tabular}{|c|c|c|c|c|c|c|c|c|c|}
\hline \multirow{3}{*}{\multicolumn{2}{|c|}{ Variable }} & \multicolumn{8}{|c|}{ Dependent variable(Increased sales ratio) } \\
\hline & & \multicolumn{2}{|c|}{$\mathrm{I}$} & \multicolumn{2}{|c|}{ II } & \multicolumn{2}{|c|}{ III } & \multicolumn{2}{|c|}{ IV } \\
\hline & & Coefficient & S.E. & \multicolumn{2}{|c|}{ Coefficient } & Coefficient & S.E. & Coefficient & S.E. \\
\hline \multirow{2}{*}{\multicolumn{2}{|c|}{$\begin{array}{c}\text { Capital } \\
\text { Number of employees }\end{array}$}} & 1.241 & 0.0001 & 0.504 & 0.0001 & 0.688 & 0.0001 & 0.546 & 0.0001 \\
\hline & & -1.260 & 0.0001 & -0.515 & 0.0001 & -0.722 & 0.0001 & -0.571 & 0.0001 \\
\hline \multirow{4}{*}{ Resources } & Human & & & -0.013 & 4.9100 & 0.023 & 5.0350 & 0.024 & 4.9730 \\
\hline & Technology & & & $0.301^{* *}$ & 0.4570 & $0.294^{* *}$ & 0.4530 & -0.118 & 1.4540 \\
\hline & Fixed-Asset & & & $0.316^{* 4}$ & 0.0380 & $0.343^{* 46}$ & 0.0380 & $0.407^{4+4 *}$ & 0.0400 \\
\hline & Process & & & 0.026 & 0.0030 & -0.018 & 0.0030 & 0.045 & 0.0030 \\
\hline \multirow{3}{*}{ Capabilities } & Searching & & & & & -0.007 & 0.0890 & -0.050 & 0.1150 \\
\hline & Absorbing & & & & & $0.205^{*}$ & 0.0910 & 0.131 & 0.1090 \\
\hline & Openness & & & & & -0.098 & 0.1870 & $-0.190^{\circ}$ & 0.2310 \\
\hline \multirow{3}{*}{\multicolumn{2}{|c|}{$\begin{array}{l}\text { Tech*Searching } \\
\text { Tech*Absorbing } \\
\text { Tech*Openness }\end{array}$}} & & & & & & & 0.147 & 1.3870 \\
\hline & & & & & & & & $0.226 \dagger$ & 0.7680 \\
\hline & & & & & & & & $0.224 \dagger$ & 2.0070 \\
\hline \multirow{2}{*}{\multicolumn{2}{|c|}{$\begin{array}{c}\text { Industry dummies } \\
\text { Adjusted } \mathrm{R}^{2}\end{array}$}} & \multicolumn{2}{|c|}{ Yes } & \multicolumn{2}{|c|}{ Yes } & \multirow{2}{*}{\multicolumn{2}{|c|}{$\begin{array}{c}\text { Yes } \\
0.298\end{array}$}} & \multicolumn{2}{|c|}{ Yes } \\
\hline & & \multicolumn{2}{|c|}{0.007} & \multicolumn{2}{|c|}{0.270} & & & 0.3 & \\
\hline \multicolumn{2}{|c|}{ F } & \multirow{2}{*}{\multicolumn{2}{|c|}{$\begin{array}{c}1.170 \\
138\end{array}$}} & \multirow{2}{*}{\multicolumn{2}{|c|}{$\begin{array}{c}6.076^{* * *} \\
138\end{array}$}} & \multicolumn{2}{|c|}{$5.483^{* * *}$} & \multicolumn{2}{|c|}{$5.065^{*+* *}$} \\
\hline \multicolumn{2}{|c|}{$\mathrm{N}$} & & & & & \multicolumn{2}{|c|}{138} & \multicolumn{2}{|c|}{138} \\
\hline
\end{tabular}

Table 5. Results of Regression Analysis (Domestic)

\begin{tabular}{|c|c|c|c|c|c|c|c|c|c|}
\hline \multirow{3}{*}{\multicolumn{2}{|c|}{ Variable }} & \multicolumn{8}{|c|}{ Dependent variable(Increased sales ratio) } \\
\hline & & \multicolumn{2}{|c|}{ I } & \multicolumn{2}{|c|}{ II } & \multicolumn{2}{|c|}{ III } & \multicolumn{2}{|c|}{ IV } \\
\hline & & Coefficient & S.E. & Coefficient & S.E. & Coefficient & S.E. & Coefficient & S.E. \\
\hline \multirow{2}{*}{\multicolumn{2}{|c|}{$\begin{array}{c}\text { Capital } \\
\text { Number of employees }\end{array}$}} & 0.577 & 0.0001 & 0.615 & 0.0001 & 0.609 & 0.0001 & 0.652 & 0.0001 \\
\hline & & -0.580 & 0.0001 & -0.578 & 0.0001 & -0.615 & 0.0001 & -0.678 & 0.0001 \\
\hline \multirow{4}{*}{ Resources } & Human & & & $0.167^{\circ}$ & 2.5330 & $0.203^{* 4}$ & 2.5460 & $0.204^{6 *}$ & 2.5100 \\
\hline & Technology & & & 0.053 & 0.3040 & 0.056 & 0.3170 & $-0.355 \dagger$ & 0.6860 \\
\hline & Fixed-Asset & & & -0.024 & 0.0370 & 0.023 & 0.0380 & 0.077 & 0.0380 \\
\hline & Process & & & 0.025 & 0.0010 & 0.058 & 0.0010 & 0.074 & 0.0010 \\
\hline \multirow{3}{*}{ Capabilities } & Searching & & & & & $0.124 \dagger$ & 0.0510 & 0.139 & 0.0610 \\
\hline & Absorbing & & & & & $0.160^{\circ}$ & 0.0520 & 0.021 & 0.0640 \\
\hline & Openness & & & & & 0.100 & 0.1560 & 0.002 & 0.1910 \\
\hline \multirow{3}{*}{\multicolumn{2}{|c|}{$\begin{array}{l}\text { Tech*Searching } \\
\text { Tech*Absorbing } \\
\text { Tech*Openness }\end{array}$}} & & & & & & & -0.002 & 0.6550 \\
\hline & & & & & & & & $0.341^{*}$ & 0.6310 \\
\hline & & & & & & & & $0.281^{*}$ & 1.3070 \\
\hline \multicolumn{2}{|c|}{ Industry dummies } & & \multicolumn{2}{|c|}{ Yes } & \multicolumn{2}{|c|}{ Yes } & \multicolumn{2}{|c|}{ Yes } \\
\hline \multicolumn{2}{|c|}{ Adjusted $\mathrm{R}^{2}$} & \multicolumn{2}{|c|}{0.006} & \multicolumn{2}{|c|}{0.017} & \multicolumn{2}{|c|}{0.042} & \multicolumn{2}{|c|}{0.070} \\
\hline \multicolumn{2}{|c|}{$\mathbf{F}$} & \multicolumn{2}{|c|}{1.218} & \multicolumn{2}{|c|}{1.378} & \multicolumn{2}{|c|}{$1.746 \dagger$} & \multicolumn{2}{|c|}{$2.042^{*}$} \\
\hline \multicolumn{2}{|c|}{$\mathrm{N}$} & \multicolumn{2}{|c|}{223} & \multicolumn{2}{|c|}{223} & \multicolumn{2}{|c|}{223} & \multicolumn{2}{|c|}{223} \\
\hline
\end{tabular}

Table 6. Results of Regression Analysis (Foreign) 
The analysis (Table 5 and 6) shows the results of regression by domestic and foreign technology transfer contracts. In domestic contracts, technology and fixed-assets variables relate positively to firm value. However, human resource has a positive effect on the performance in technology transfer with foreign countries. The results of Table 7 and 8 are divided by licensing-in and technological cooperation. Fixed-assets resource is important when companies have technological contracts for licensing in. The technology resource variable can affect to business performance positively when they have technological cooperation.

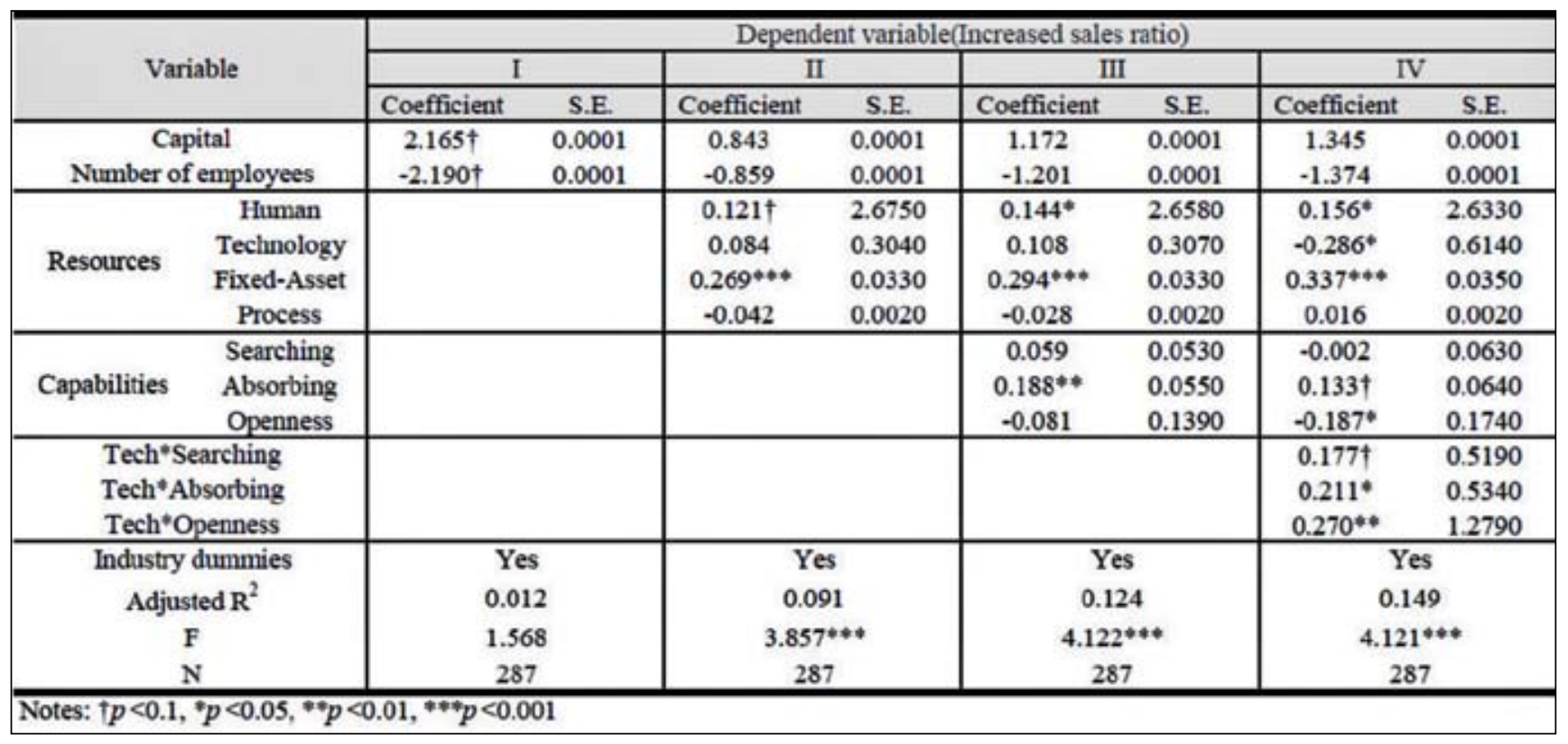

Table 7. Results of Regression Analysis (Licensing-In)

\begin{tabular}{|c|c|c|c|c|c|c|c|c|c|}
\hline \multirow{3}{*}{\multicolumn{2}{|c|}{ Variable }} & \multicolumn{8}{|c|}{ Dependent variable(Increased sales ratio) } \\
\hline & & \multicolumn{2}{|c|}{ I } & \multicolumn{2}{|c|}{ II } & \multicolumn{2}{|c|}{ III } & \multicolumn{2}{|c|}{ IV } \\
\hline & & Coefficient & S.E. & Coefficient & S.E. & Coefficient & S.E. & Coefficient & S.E. \\
\hline \multirow{2}{*}{\multicolumn{2}{|c|}{$\begin{array}{c}\text { Capital } \\
\text { Number of employees }\end{array}$}} & 1.175 & 0.0001 & 0.890 & 0.0001 & 1.213 & 0.0001 & 1.143 & 0.0001 \\
\hline & & -1.260 & 0.0001 & -1.013 & 0.0001 & -1.441 & 0.0001 & -1.318 & 0.0001 \\
\hline \multirow{4}{*}{ Resources } & Human & & & -0.064 & 6.1660 & 0.024 & 6.3130 & -0.046 & 6.0890 \\
\hline & Technology & & & $0.568^{*+*}$ & 0.5660 & $0.526^{+4+}$ & 0.5540 & -0.420 & 1.7460 \\
\hline & Fixed-Asset & & & 0.091 & 0.0400 & 0.144 & 0.0390 & 0.158 & 0.0370 \\
\hline & Process & & & 0.138 & 0.0030 & 0.044 & 0.0030 & 0.169 & 0.0030 \\
\hline \multirow{3}{*}{ Capabilities } & Searching & & & & & $0.229 \dagger$ & 0.1040 & 0.059 & 0.1280 \\
\hline & Absorbing & & & & & $0.223 \dagger$ & 0.1090 & -0.106 & 0.1480 \\
\hline & Openness & & & & & 0.022 & 0.2390 & -0.057 & 0.2680 \\
\hline \multirow{3}{*}{\multicolumn{2}{|c|}{$\begin{array}{l}\text { Tech*Searching } \\
\text { Tech*Absorbing } \\
\text { Tech*Openness }\end{array}$}} & & & & & & & 0.295 & 1.3480 \\
\hline & & & & & & & & $0.738^{*}$ & 1.7210 \\
\hline & & & & & & & & 0.140 & 4.7690 \\
\hline \multicolumn{2}{|c|}{ Industry dummies } & \multicolumn{2}{|c|}{ Yes } & \multicolumn{2}{|c|}{ Yes } & \multicolumn{2}{|c|}{ Yes } & \multicolumn{2}{|c|}{ Yes } \\
\hline \multicolumn{2}{|c|}{ Adjusted $\mathrm{R}^{2}$} & \multicolumn{2}{|c|}{0.023} & \multicolumn{2}{|c|}{0.350} & \multicolumn{2}{|c|}{0.396} & \multicolumn{2}{|c|}{0.466} \\
\hline \multicolumn{2}{|c|}{$\mathbf{F}$} & \multicolumn{2}{|c|}{1.291} & \multicolumn{2}{|c|}{$4.929^{\circ * \bullet}$} & \multicolumn{2}{|c|}{$4.681^{\circ+*}$} & \multicolumn{2}{|c|}{$4.989^{\bullet \bullet \bullet}$} \\
\hline \multicolumn{2}{|c|}{$\mathrm{N}$} & \multicolumn{2}{|c|}{74} & \multicolumn{2}{|c|}{74} & \multicolumn{2}{|c|}{74} & \multicolumn{2}{|c|}{74} \\
\hline
\end{tabular}

Table 8. Results of Regression Analysis (Technological Cooperation) 


\section{Discussion and Conclusions}

Table 9 and 10 show the results of summarized regression models. The number of stars refers to the degree of effectiveness of resources and capabilities. The human, technology, and fixed-assets resources have a positive effect on increased sales ratio, but the process resource has no effect. The human resource is the core resource of firms. All kinds of works are started by a firm's human resource. There is no doubt human resource is the best resource a firm can have. A sample of this research is the contract of technology transfer. The technology resource moves each other companies on technology transfer. Even if a firm acquires technologies from other firms, the ability of its own technology assets is very important. The acquired technology can be used as another type of technology or be modified as an advanced technology when the firm has enough inner technology capacity. Fixed-assets include products manufacturing line, the size of plants, and R\&D equipments. A large fixed-assets ratio means that the capability of production and research is sufficient enough to help the firm's innovation system.

\begin{tabular}{|c|c|c|c|c|}
\hline & \multicolumn{4}{|c|}{ Resources } \\
\hline & Human & Technology & Fixed-Asset & Process \\
\hline Total & 云 & $\star \star$ & $\star \star \star$ & \\
\hline $\begin{array}{c}\text { Large Enterprise } \\
\text { SMEs }\end{array}$ & & $\star$ & $\begin{array}{c}\star \star \star \\
\star\end{array}$ & $\hat{4}$ \\
\hline $\begin{array}{c}\text { Domestic } \\
\text { Foreign }\end{array}$ & $\star$ & $\star \star$ & $\star \star$ & \\
\hline $\begin{array}{l}\text { Licensing-in } \\
\text { Tech Coop }\end{array}$ & $\Delta$ & $\star \star \star$ & $\star \star \star$ & \\
\hline
\end{tabular}

Table 9. Impacts of Resources

\begin{tabular}{|c|c|c|c|}
\hline & \multicolumn{3}{|c|}{ Capabilities } \\
\hline & Searching & Absorbing & Openness \\
\hline Total & $\star \star$ & $\star \star \star$ & $\star \star$ \\
\hline $\begin{array}{c}\text { Large Enterprise } \\
\text { SMEs }\end{array}$ & $\star$ & मै & $\star \star$ \\
\hline $\begin{array}{c}\text { Domestic } \\
\text { Foreign }\end{array}$ & & 丸 & $\begin{array}{l}\text { 수 } \\
\star\end{array}$ \\
\hline $\begin{array}{l}\text { Licensing-in } \\
\text { Tech Coop }\end{array}$ & मे & $\begin{array}{l}\star \\
\star\end{array}$ & $\star \star$ \\
\hline
\end{tabular}

Table 10. Impacts of Capabilities 
Capabilities to manage technologies are all important for business benefit. Searching, absorbing, and openness capabilities have a significant positive effect on firm value. Companies using technology transfer usually acquire their innovation from either domestic or foreign country. Greater searching ability will yield more innovative sources. The firm with a branch in a foreign country will more easily find various, powerful and unique target technology. Making one's own technology from adopted technologies refers to absorbing ability of a firm. It indicates that the firm has its own research and development abilities and that it can make, modify, and advance acquired technologies from other firms. Many of Korean firms started their initial business from imitating technologies from American or Japanese companies, but did their best in advancing the imitated technology. Thus, a firm with self-R\&D ability will gain more profits. The variable of openness refers to a firm's tendency toward external companies. Technology information is a sensitive issue where confidentiality is crucial for firms. If a firm does not want to share their technology, they will only conduct R\&D activities internally. However, sharing ideas and information on technologies give more leeway to innovative and unique thinking. Also, it can be profitable to outsource technologies in the firm's weaker or non-core areas of research. This openness capability is the best example of an open innovation model. Technology transfer companies that have more openness tendency will be more successful.

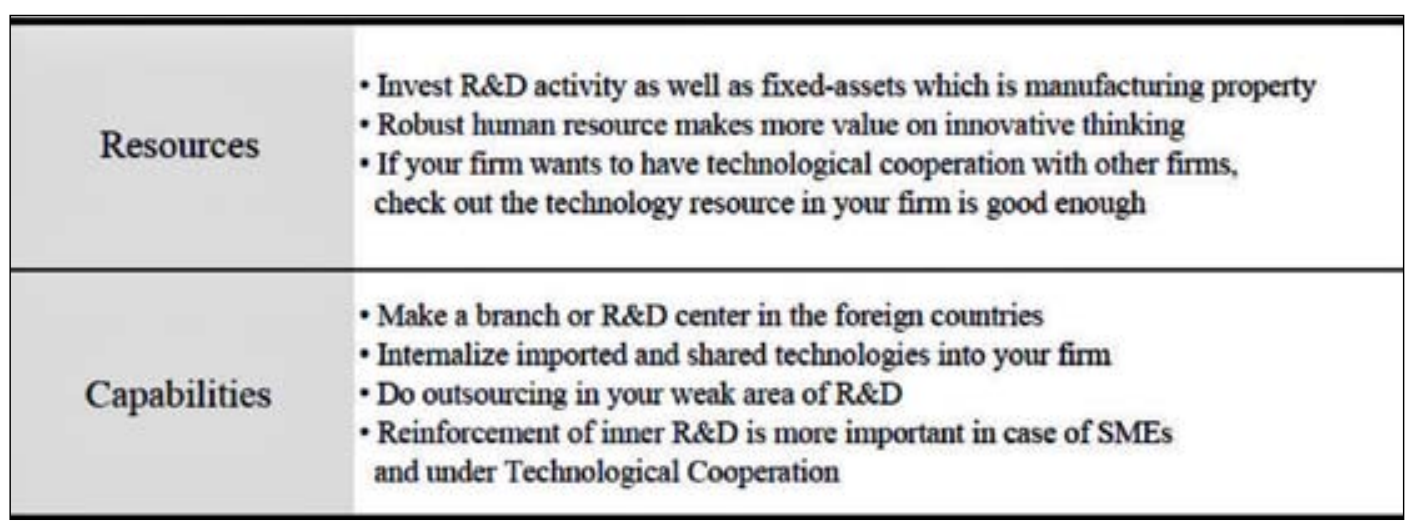

Table II. Strategies of Technology Transfer Companies

Based on the results, several strategies can be derived for technology transfer companies (Table II). Under the resource-based view, the firm should invest in $R \& D$ activities as well as fixed-assets, which is a manufacturing property, and R\&D equipments. Robust human resource makes more value on innovative thinking; therefore, if a firm wants to have technological cooperation with other firms, it should check to see if its technology resources are good enough. Under the capability-based view, reinforcement of inner R\&D is more important in case of SMEs and under technological cooperation. Also, a firm should make a branch or R\&D center in foreign countries, internalize imported and shared technologies into the firm, and outsource technologies in the firm's weak area of R\&D.
These strategies can also be used for national R\&D policies. The policy maker or national institute supporting SMEs can help them grow their resources and capabilities. Sending a specialist from large companies and national institutes is a good way to improve a firm's human resource. Encouraging technology transfer from universities and national institutes can also be helpful to provide the power of technology. From the searching capability view perspective, in order to gain ideas and information on foreign countries, the government can use national association, such as KOTRA (Korea Trade Association).

Although this research has found that some resources and capabilites can positively affect financial performance, the sample is not representative of countries other 
than South Korea. Secondly, these findings may not be applicable to economic sectors other than those in this study. Additionally, though this research examined the relationships between many independent variables and increased sales ratio, it ignored the time lag that often occurs in technology transfer. This research suggest that future researchers examine technology transfer companies in other countries such as the United States, Europe and Japan, and take into account the effects of technology transfer effectiveness time lag.

\section{References}

AGRAWAL, A. and G. Mandelker (1986), Corporate Capital Expenditures and Managerial Stock Holding: Agency or Signalling?, Mimeo.

ALBERT, M., Avery, D., Narin, F., and McAllister, P. (1990), "Direct validation of citation counts as indicators of industrially important patterns", Research Policy, 20(3), 25I-259.

ALCHIAN, A. and H. Demsetz (1972), "Production, Information Costs, and Economic Organization", American Economic Review, 62, 777-795.

ARROW, K. (1969), "Classificatory notes on the production and transmission of technological knowledge", American Economic Review, 59, 29-35.

BALDWIN, J.R. and Hanel, P. (2003), Innovation and Knowledge Creation in an Open Economy, Cambridge: Cambridge University Press.

BARNEY, J. B. (199I), "Firm resources and sustained competitive advantage", Journal of Management, 17, I, 99-120.

BASANT, Rakesh and Brian Fikkert (1996), "The effects of R\&D, foreign technology purchase, and domestic and international spillovers on productivity in Indian firms", Review of Economics \& Statistics, 78(2), 187-199.

BRAGA, H., and Wilmore, L. (1991), "Technological imports and technological effort: an analysis of their determinants in Brazilian firms", The Journal of Industrial Economics, 39(4), 42I-432.

BRANCH, B. (1974), "Research and Development Activity and Profitability-A Distributed Lag Analysis", Journal of Political Economy, 82(5), 999-101I
BROCKHOFF, K. (1992), "Instruments for patent data", Technovation, I2(I), 45I-458.

BROWN, S. L. and Eisenhardt, K. M. (1995), "Product Development: Past Research, Present Findings and Future Directions", Academy of Management Review, 20(2), 343-378.

Brown, J. S. and Duguid, P. (2000), The Social Life of Information, Boston, MA: Harvard Business School Press. Buhner, R. (1987), "Assessing international diversification of West German corporations", Strategic Management Journal, 8, 25-37.

CAMP, S. M. and Sexton, D. L. (1992) “Technology Transfer and Value creation: Extending the theory beyond information exchange", Technology Transfer, spring-summer.

CHAN, S. H., J.D. Martin, and J. W. Kensinger (1990), "Corporate research and development expenditures and share value", Journal of Financial Economics, 26(August), 255-276.

CHESBROUGH, Henry (2003), OPEN INNOVATION: The New Imperative for creating and profiting from technology, Boston, MA: Harvard Business School Press, 34-39, 45, 51, 52-57

CHESBROUGH, Henry (2003), "The Era of Open Innovation”, Sloan Management Review Summer, 35-4I.

CHESBROUGH, Henry (2003), Open Innovation, Cambridge, MA: Harvard University Press.

CHEN, J., Chen, Y., and Vanhaverbeke W. (2007), Open Innovation Strategy and Catch-up of Chinese firms.

CHO, S. (1989), Capital Structure, Distribution of Stock Ownership Claims, and Research and Development Expenditures. Unpublished Dissertation. Washington Univ.

CHUANG, Y., and Lin, C. (1999), "Foreign direct investment, R\&D and spillover efficiency: Evidence from Taiwan's manufacturing firms", Journal of Development Studies, 35(4), II7-I37.

COBB, S. L. and Baker, T. S. (1992), "A Model of crosscultural Training in the Transfer of Technology", Technology Transfer, 17(4), 8-15. 
COHEN, W. M. and Klepper, S. (1996), "A reprise of size and R\&D”, Economic Journal, 106, 925-95I.

CONNER, K. (1991), "A historical comparison of resource-based theory and five schools of thought within Industrial Organization economics: Do we have a new theory of the firm?", Journal of Management, 17, 12I-154.

CONNER, K. R. and C. K. Prahalad (1996), "A resourcebased theory of the firm: Knowledge versus opportunism", Organization Science, 7, 477-50I.

COVIELLO, N. E. and Munro, H. J. (1995), "Growing the entrepreneurial firm: Networking for international market development", European Journal of Marketing, 29(7), 49-61.

DANNIELS, J. D. \& Bracker, J. (1989), "Profit performance: Do foreign opertations make a difference?", Management International Review, 29(I), 45-56.

DEOLALIKAR, A. and R.E. Evenson (1989), Technology production and technology purchase in Indian industry: An econometric analysis, Review of Economics and Statistics, 687-692.

DIERICKX, I., and Cool, K. (1989), "Asset stock accumulation and sustainability of competitive advantage", Management Science, 35(I2), I504-I5II.

DUNNING, J. H. (1977), Trade, Location of Economic Activity and the MNE: A Search for An Eclectic Theory in B. Ohlin, P. O. Hesselborn, and P. M. Wijkman, eds., The International Allocation of Economic Activity, Holmes and Meier: N.Y.

DUNNING, J. H. (1979), "Explaining Changing Patterns of International Production: In Defence of the Eclectic Theory", Oxford Bulletin of Economics and Statistics, November , 269-295

DUSSAUGE, P., Garrette, B., \& Mitchell, W. (2000), "Learning from competing partners: outcomes and durations of scale and link alliances in Europe, North America, and Asia", Strategic Management Journal, 2I, 99-126.

DYER, J. H., \& Singh, H. (1998), "The relational view: cooperative strategy and sources of interorganizational competitive advantage," Academy of Management Review, 23, 660-679.
EUH, Yoon-Dae (1996), International Business, Gyeonggi: Hakhyunsa.

FEAMS, D., Looy, B. V. and Debackere, K. (2005), “Interorganizational Collaboration and Innovation: Toward a Portfolio Approach", The Journal of Product Innovation Management, 22, 238-250.

CONTRACTOR, F. J., Kundu, S. K. \& Hsu, C. C. (2003), "A three-stage theory of international expansion: the link between multinationality and performance in the service sector", Journal of International Business Studies, 34(I), $5-18$.

FOSTER, G. (197I) "Traditional cultures and the impact of technological change”, Harvard Business Review, Nov/Dec.

GeRINGER, J. M., Beamish, P. W. \& da Costa, R. C. (1989), "Diversification strategy and internationalization: implications for MNE performance," Strategic Management Journal, 10, 109-119.

GRANT, R. (199I). "The resource-based theory of competitive advantage: Implications for strategy formulation", California Management Review, 33(Spring), II4-I35.

GRANT, R. M. (1996), "Toward a knowledge-based theory of the firm", Strategic Management Journal, I7(Winter Special Issue), 109-122.

GULATI, R., \& Singh, H. (1998), "The architecture of cooperation: Managing coordination costs and appropriation concerns in strategic alliances", Administrative Science Quarterly, 43, 78I-814.

HAGEDOORN, J. (1993), "Understanding the rational of strategic technology partnering: Interorganizational modes of cooperation and sectoral differences", Strategic Management Journal, 14, 37I-385.

HAGEDOORN, J. and Duysters, G. (2002), "Learning in dynamic inter-firm networks - The efficacy of quasi-redundant contacts", Organization Studies, 23(4), 525-548.

HARHOFF, D., Narin, F., Scherer, F. M., and Vopel, K. (1999), "Citation Frequency and the Value of Patented Inventions", The Rev. of Economics and Statistics, 8I(3), 5II515. 
HIRSCHEY, M., and Weygandt, J. J. (1985), "Amortization policy for advertising and research and development expenditures", Journal of Accounting Research, 23, 326-335.

HITT, M. A., Tyler, B. B., Hardee, C., \& Park. D. (1995), "Understanding strategic intent in the global market place", Academy of Management Executive, 9(2), 12-19.

HITT, M. A., Dacin, M., Levitas, E., Arregle, J. L., \& Borza, A. (2000), "Partner selection in emerging and developed market contexts: Resource-based and Organizational learning perspectivecs", Academy of Management Journal, 43, 449-467.

HU, A. G. Z., Jefferson, G. H. and Jinchang, Q. (2005), "R\&D and Technology Transfer: Firm-Level Evidence from Chinese Industry", Review of Economics and Statistics, 87(4), 780-786.

JENSEN, M. and W. Meckling (1976), "Theory of Firms: Managerial Behavior, Agency Costs and Ownership Structure", Journal of Financial Economics, 3(4), 305-360.

JOHN, R. B. and Peter, H. (2003), Innovation and Knowledge Creation in an Open Economy, Cambridge: Cambridge University Press, I30-155.

KATILA, R. (2002), "New product search over time: past ideas in their prime?" Academy of Management Journal, 45, 995-1010.

KATILA, R, Ahuja, G. (2002), "Something old, something new: a longitudinal study of search behavior and new product introduction", Academy of Management Journal, 45(8), II83-II94.

KIM, W. S. and Lyn, E. O. (1987), "Foreign Direct Investment Theories, Entry Barriers and Reverse Investments in the US Manufacturing Industries", Journal of International Business Studies, Summer, 53-66.

KOGUT, B. (1988), "Joint ventures The theoretical and empirical perspectives", Strategic Management Journal, 9, 319-332.

KOGUT, B. and U. Zander (1992), "Knowledge of the firm, combinative capabilities, and the replication of technology”, Organization Science, 3, 383-397.
KOGUT, B., and Zander, U. (1993), "Knowledge of the firm and the evolutionary theory of the multinational corporation”, Journal of International Business Studies, 24, 625-645.

LEE, C., Lee, K., and Lubatkin, M. (1998), "Relative absorptive capacity and interorganizational learning", Strategic Management Journal, 19, 467-477.

LEE, J. (1996), "Technology imports and R\&D efforts of Korean manufacturing firms", Journal of Development Economics, 50(I), 197-210.

LEVY, David M., and Nestor E. Terleckyj (1983), "Effects of government R\&D on private R\&D investment and productivity: a macroeconomic analysis", Bell Journal of Economics, 14, 55I-56I.

LUNDVALL, B-A. (1992), National Systems of Innovation: Towards a Theory of Innovation and Interactive Learning, London: Pinter.

MAHONEY, J. T. and Pandian, J. R. (1992), "The resourcebased view within the conversation of strategic management”, Strategic Management Journal, 13, 363-380.

MAHONEY, J. (200I), "A resource-based theory of sustainable rents", Journal of Management, 27, 65I-660.

META, F. J., W. L. Fuerst, J.B. Barney (1995), “Information technology and sustained competitive advantage: a resource-based analysis", MIS Quarterly, 19(4), 487-505.

MILLER, J. \& Pras, B. (1980), "The effects of multinational and export diversification on the profit stability of US corporations", South Economic Journal, 46(3), 792-805.

MOTTNER, S. and J. P. Johnson (2000), "Motivations and Risks in International Licensing: A Review and Implications for Licensing to Transitional and Emerging Economies", Journal of World Business, 35(2), I7I-I88.

NIETO, M. J. and Santamaria, L. (2007), "The Importance of Diverse Collaborative Networks for the Novelty of Product Innovation”, Technovation, 27(6-7), 367-377.

ODAGIRI, H. (1983), "R\&D Expenditures, Royalty Payments, and Sales Growth in Japanese Manufacturing Corporations", Journal of Industrial Economics, 32(I), 6I-7I. 
PARKER, D., Zilberman, D., and Castillo, F. (1998), "Offices of Technology Transfer”, Choices, 13(I), 19-25.

PARKER, D. and Zilberman, D. (1993), "University Technology Transfers: Impacts on Local and U.S. Economies", Contemporary Policy Issues, II (2), 87-99.

PENROSE, E. T. (1959), The Theory of the Growth of the Firm, Oxford: Blackwell.

PILKINGTON, A. (2004), "Technology portfolio alignment as an indicator of commercialization: an investigation of fuel cell patenting", Technovation, 24(I0), 76I-77I.

POWELL, W. W., Koput, K. W. and Smith-Doerr, L. (1996), "Inter-organizational Collaboration and the Local of Innovation: Networks of Learning in Biotechnology", Administrative Science Quarterly, 4I, II6-I45.

PRIEM, R. and J. Butler (200I), "Is the resource-based "view" a useful perspective for strategic management research?", Academy of Management Review, 26, 22-40.

QIAN, G. (2002), "Multinationality, product diversification, and profitability of emerging US small- and mediumsized enterprises", Journal of Business Venturing, 17, 611-633.

RAMSAWAMY, K.(1993), "Multinationality and performance: an empirical examination of the moderating effect of configuration", Proceedings of Academy of Management, |42-146.

REDDY, A. M. and Zhao, L. (1990), "International Technology Transfer: A Review”, Research Policy, 19, 285-307.

ROSENKOPF, L. and Nerkar, A. (200I), "Beyond Local Research: Boundary-Spanning, Exploration, and Impact in the Optical Disk Industry", Strategic Management Journal, 22(4), 287-306.

SAKKAB, N. Y. (2002), "Connect and Develop Complements Research and Develop at P\&G", Research Technology Management, 45(2), 38-45.

SCOTT, C. and Brown, J. S. (1999), "Bridging Epistemologies: The Generative Dance between Organizational Knowledge and Organizational Knowing", Organization Science, I0(4), 38I-400.
SOUGIANNIS, T. (1994), "The Accounting Based Valuation of Corporate R\&D”, The Accounting Review, 69(I), 44-68.

SPANOS, Y.E., and S. Lioukas (200I), "An examination into the casual logic of rent generation: contrasting Porter's competitive strategy framework and the resource-based perspective", Strategic ManagementJournal, 22(I0), 907-934.

STUART, T. E. (1998), "Network positions and propensities to collaborate: an investigation of strategic alliance formation in a high-technology industry," Administrative Science Quarterly, 43, 668-698.

STUART, T. E. (2000), “Interorganizational alliances and the performance of firms: A study of growth and innovation rates in a high-technology industry", Strategic Management Journal, 2I, 79I-8II.

SZEWCZYK, S. H., G. P. Tsetsekos and Z. Zantout (1996), "The Valuation of Corporate R\&D Expenditures: Evidence from Investment Opportunities and Free Cash Flow", Financial Management, 25, 105-II0.

SZULANSKI, G. (1996), "Exploiting Internal Stickiness: Impediments to the Transfer of Best Practice", Strategic Management Journal, Winter Special Issue, 17, 27-43.

TALLMAN, S. \& Li, J. T. (1996), "Effects of international diversity and product diversity on the performance of multinational firms", Academy of Management Journal, 39, 179-196.

TEECE, D. J. (1977), “Technology transfer by multinational firms: The resource cost of transferring technological know-how", Economic Journal, 87, 242-26I.

THURSBY, J. and Thursby, M. (2000), "Industry Perspectives on Licensing University Technologies: Source and Problems", The Journal of the Association of University Technology Managers, 12, 9-22.

TIHANYI, L. and A. S. Roath (2002), "Technology Transfer and Institutional Development in Central and Eastern Europe," Journal of World Business, 37, 188-198

TWISS, Brian (1974), Managing Technological Innovation, Longman Co., New York. 
VAN DE VRANDE, V., et al. (2006), "Choosing Governance Modes for External Technology Sourcing", R\&D Management, 36(3), 347-363.

VON HIPPEL, E. (1988), The Sources of Innovation, New York: Oxford University Press.

WERNERFELT, B. (1984). "A resource-based view of the firm”, Strategic Management Journal, 5, 17I-180.

WEST, J. and Gallagher, S. (2006), "Challenges of Open Innovation: The Paradox of Firm Investment in Opensource Software", R\&D Management, 36(3), 319-33I.

YEOH, Poh-Lin and Roth, Kendall (1999), "An empirical analysis of sustained advantage in the U.S. pharmeceutical industry: Impact of firm resources and capabilities", Strategic Management Journal, 20, 637-653.

ZHAO, H. (1995), "Technology imports and their impact on the enhancement of China's indigenous technological capability”, Journal of Development Studies, 31(4), 585-602.

DATA Analysis, Retrieval, and Transfer System (DART), hrrp://dart.fss.or.kr

WORLDWIDE Intellectual Property Search (WIPS), http://www.wips.co.kr

KOREA EXCHANGE (KRX), http://www.krX.co.kr 